\section{Soil Calcium Status Unrelated to Tipburn of Romaine Lettuce}

\author{
Timothy K. Hartz ${ }^{1}$ and Paul R. Johnstone \\ Department of Plant Sciences, University of California, 1 Shields Avenue, \\ Davis, CA 95616

\begin{abstract}
Richard F. Smith and Michael D. Cahn
University of California Cooperative Extension, 1432 Abbott Street, Salinas, CA 93901
\end{abstract}

Additional key words. soil testing, saturated paste, soil solution, fertigation, transpiration, Lactuca sativa $\mathrm{L}$.

\begin{abstract}
Application of calcium (Ca) fertilizers is a common practice of California lettuce growers to minimize the occurrence and severity of tipburn, particularly in romaine lettuce (Lactuca sativa $\mathbf{L}$. var. longifolia Lam.). An evaluation of the effect of soil Ca availability on the severity of tipburn in romaine lettuce was conducted in the Salinas Valley of central California in 2005 to 2006. Twenty representative soils from this region were evaluated for $\mathrm{Ca}$ availability by ammonium acetate extraction, saturated paste extraction, and extraction of soil solution through centrifugation of soil at field-capacity moisture content. Soil solution $\mathrm{Ca}$ in these soils was generally high, ranging from 5 to 80 mmolc $\cdot L^{-1}$, representing $44 \%$ to $71 \%$ of cations on a charge basis. Soil solution Ca was highly correlated with saturated paste $\mathrm{Ca}\left(r^{2}=0.70\right)$ but not with exchangeable $\mathrm{Ca}\left(r^{2}=\right.$ 0.01). However, saturated paste extraction significantly underestimated soil solution $\mathrm{Ca}$ concentration (regression slope $=0.19$ ). A survey of 15 commercial romaine lettuce fields showed tipburn severity to be unrelated to either leaf Ca concentration or soil $\mathrm{Ca}$ availability. The most severe tipburn was observed in fields in which transpiration was reduced by foggy weather during the final 2 weeks of growth. Ca fertilizers (calcium nitrate, calcium thiosulfate, and calcium chloride) applied through drip irrigation during the final weeks of lettuce growth were ineffective in increasing romaine leaf $\mathrm{Ca}$ concentration in three field trials; tipburn was present in only one trial, and $\mathrm{Ca}$ fertigation had no effect on tipburn severity. We conclude that under typical field conditions in this region, tipburn severity is primarily a function of environmental conditions. Soil $\mathrm{Ca}$ availability plays no substantive role in tipburn severity, and $\mathrm{Ca}$ fertigation does not improve lettuce Ca uptake or reduce tipburn.
\end{abstract}

Tipburn of romaine lettuce is a serious quality defect, which causes significant economic loss to lettuce growers in the Salinas Valley of California. This defect is particularly problematic for the producers of freshcut salad mixes because the presence of even a few affected leaves in a consumer product is unacceptable. Tipburn is generally recognized as a localized calcium $(\mathrm{Ca})$ deficiency that induces collapse and necrosis of the margins of actively expanding leaves (Collier and Tibbitts, 1982). Under field conditions, tipburn development is often related to factors other than soil Ca supply. Tipburn occurs primarily in the final weeks before harvest, when crop growth rate is most rapid. Environmental conditions such as high light intensity (Tibbitts and Rao, 1968) or warm temperatures (Rao, 1966) that encourage rapid growth also promote tipburn. Because Ca moves primarily by transpirational mass flow in the xylem (Clarkson, 1984), inner leaves that are enclosed within the develop-

Received for publication 22 Mar. 2007. Accepted for publication 24 June 2007.

${ }^{1}$ To whom reprint requests should be addressed; e-mail tkhartz@ucdavis.edu. ing head are particularly prone to the disorder because of their low transpiration rate.

Effective tipburn prevention measures have proven elusive. Cultivars vary considerably in tipburn susceptibility (Collier and Tibbitts, 1982; Ryder and Waycott, 1998), but no commercially acceptable romaine cultivar has been developed that is reliably tipburn-resistant. Under controlled conditions, $\mathrm{Ca}$ application to soil, foliage, or in nutrient solution has reduced tipburn (Ashkar and Ries, 1971; Sonneveld and van den Ende, 1975; Thibodeau and Minotti, 1969). Frantz et al. (2004) and Goto and Takakura (1992) reduced tipburn by blowing air onto the developing leaves, thereby increasing transpiration. However, under field conditions, success in reducing tipburn has been limited. Misaghi and Matyac (1981) found that soil $\mathrm{Ca}$ application at rates as high as $160 \mathrm{~kg} \cdot \mathrm{ha}^{-1}$ reduced tipburn in only one of six fields. Bangerth (1979) and Collier and Tibbitts (1982) concluded that in soils normally used for lettuce production, soil Ca supply was not a significant factor in tipburn development.

Despite the generally poor success reported for soil $\mathrm{Ca}$ application, fertigation of products such as calcium nitrate or calcium thiosulfate remains a common practice in the
California lettuce industry. Ca fertigation is done without regard for soil test $\mathrm{Ca}$ level on the belief that in the high $\mathrm{pH}$, alkaline soils typical of this region, the common soil test procedure (ammonium acetate extraction; Thomas, 1982) does not provide an accurate estimate of soil $\mathrm{Ca}$ availability. This study was undertaken to determine whether soil $\mathrm{Ca}$ availability played any substantive role in tipburn development in romaine lettuce under representative field conditions and whether Ca fertigation could improve lettuce $\mathrm{Ca}$ uptake and decrease tipburn severity.

\section{Materials and Methods}

Characterization of soil calcium availability. Soil samples were collected from 20 representative vegetable fields in central California in 2005. The fields were chosen to cover the range of soil texture and $\mathrm{pH}$ commonly used for lettuce production. Samples (top $30 \mathrm{~cm}$ ) were air-dried, sieved through a 2-mm screen, and subjected to ammonium acetate extraction (Thomas, 1982) and saturated paste extraction (Rhoades, 1982). Additionally, a centrifugation method similar to that of Thibault and Sheppard (1992) was used to extract soil solution. In brief, 30 -g samples of air-dried soil were placed in polyethylene cylinders and wetted with deionized water to field capacity (defined as the gravimetric water content at a soil moisture tension of 0.02 $\mathrm{MPa})$. The samples were allowed to equilibrate overnight and then centrifuged for $40 \mathrm{~min}$ at $2000 \mathrm{rpm}$, equivalent to a force of $\approx 800 \mathrm{~g}$. The filtered soil solutions collected were analyzed for $\mathrm{Ca}$, magnesium $(\mathrm{Mg})$, potassium $(\mathrm{K})$, and sodium $(\mathrm{Na})$ concentration by atomic emission spectrometry.

Lettuce tipburn survey. Fifteen fields of romaine lettuce were sampled in 2005 to 2006 to document the relationships among soil $\mathrm{Ca}$ status, weather conditions, leaf $\mathrm{Ca}$ concentration, and tipburn severity. Fields were distributed throughout the Salinas Valley; harvest dates ranged from April through September. Soil samples (top $30 \mathrm{~cm}$ ) were collected and analyzed for $\mathrm{Ca}, \mathrm{Mg}, \mathrm{K}$ and $\mathrm{Na}$ in saturated paste extracts. At commercial maturity, 24 randomly selected plants per field were evaluated for tipburn. Each plant was split longitudinally, and the number of leaves per plant exhibiting tipburn was recorded. From each field, a composite sample comprised of inner leaves (those $\approx 10$ to $15 \mathrm{~cm}$ long from within the "heart" of the plant) from all 24 plants were oven-dried, ground, and analyzed for Ca concentration by inductively coupled plasma atomic emission spectrometry (Meyer and Keliher, 1992) after microwave digestion with nitric acid and hydrogen peroxide (Sah and Miller, 1992).

For each field, daily air temperature and reference evapotranspiration $\left(\mathrm{ET}_{\mathrm{o}}\right.$; Goldhamer and Snyder, 1989) data were obtained from weather stations of the California Irrigation Management Information System (CIMIS) for the final 2 weeks of growth, the period when tipburn typically develops. Given the 
importance of transpiration on Ca movement to developing leaves (Collier and Tibbitts, 1982), and plant growth rate on tipburn susceptibility (Cox et al., 1976), a daily transpiration index was calculated by dividing daily $\mathrm{ET}_{\mathrm{o}}(\mathrm{mm})$ by the number of degree days (DD). DD were calculated by the formula:

$[(\max$. air temp. + min. air temp. $) / 2]-5=\mathrm{DD}$

using $5{ }^{\circ} \mathrm{C}$ and $30{ }^{\circ} \mathrm{C}$ as lower and upper temperature thresholds, respectively. This index provided an estimate of crop transpiration per unit growth potential; lower values indicated greater potential for tipburn.

Calcium fertigation effects on lettuce. Two field trials were conducted in the Salinas Valley in 2005 and another in 2006 to evaluate the effects of soluble $\mathrm{Ca}$ applied through drip irrigation on romaine lettuce growth, inner leaf $\mathrm{Ca}$ concentration, and tipburn severity. Soil characteristics and cultural details are given in Table 1. In the 2005 trials, three $\mathrm{Ca}$ fertilizers [calcium nitrate $(\mathrm{CN})$, calcium thiosulfate (CTS), and calcium chloride] were injected into the drip systems twice, the first application $\approx 3$ weeks preharvest and the second $\approx 1$ week preharvest. $\mathrm{Ca}$ fertigation was applied during this timeframe because this is the part of the season in which tipburn most commonly occurs. Injections of $17 \mathrm{~kg} \cdot \mathrm{ha}^{-1} \mathrm{Ca}$ were made over $4 \mathrm{~h}$ at a concentration of $\approx 15$ mmolc $\cdot \mathrm{L}^{-1} \mathrm{Ca}$. In the 2006 trial, two $\mathrm{Ca}$ fertilizers (CN and CTS) were injected at $28 \mathrm{~kg} \cdot \mathrm{ha}^{-1} \mathrm{Ca}$ (at $\approx 22 \mathrm{mmolc} \cdot \mathrm{L}^{-1} \mathrm{Ca}$ ) in a single application 1 week before harvest. These $\mathrm{Ca}$ applications simulated common commercial rates and timing. In all trials, the Ca fertigation treatments were compared with a control treatment receiving no $\mathrm{Ca}$ fertigation. Irrigation water $\mathrm{Ca}$ ranged among trials from 2 to $5 \mathrm{mmolc} \cdot \mathrm{L}^{-1}$. A randomized complete block experimental design was used in all trials with five single-bed replicates $120 \mathrm{~m}$ long. In the 2005 trials, soil beds were $2 \mathrm{~m}$ wide with six plant rows and three drip irrigation lines; in 2006, the beds were $1 \mathrm{~m}$ wide with two plant rows and one drip line. The daily transpiration index in the last 2 weeks of growth averaged $0.43,0.32$, and $0.28 \mathrm{~mm} \mathrm{ET}_{\mathrm{o}} / \mathrm{DD}$ in trials 1, 2, and 3, respectively.

In each trial, the percentage of marketable plants was determined by taking plant counts before and after the commercial harvest. Before commercial harvest, 32 random plants per plot were evaluated for total fresh weight. Sixteen plants per plot were evaluated for tipburn as previously described. A composite sample of inner leaves was collected from each plot, oven-dried, ground, and analyzed for $\mathrm{Ca}$ concentration.

\section{Results}

Characterization of soil calcium availability. The soils tested ranged in soil solution $\mathrm{Ca}$ from 5 to $80 \mathrm{mmolc} \cdot \mathrm{L}^{-1}$, representing $44 \%$ to $71 \%$ of cations in soil solution on a charge basis; the soils averaged 34 mmolc $\cdot \mathrm{L}^{-1} \mathrm{Ca}$, representing $57 \%$ of cation charges. Soil solution $\mathrm{Ca}$ was highly correlated with saturated paste $\mathrm{Ca}\left(r^{2}=0.70\right)$ but not exchangeable $\mathrm{Ca}\left(r^{2}=0.01\right.$; Fig. 1$)$. Saturated paste extraction yielded significantly lower $\mathrm{Ca}$ concentrations than in soil solution (regression slope $=0.19$ ). Even after adjusting for the disparity in soil water content (preparation of saturated paste extracts required between $160 \%$ and $200 \%$ of field capacity moisture content), saturated paste $\mathrm{Ca}$ averaged only $35 \%$ of soil solution $\mathrm{Ca}$.

Lettuce tipburn survey. The percentage of romaine plants showing tipburn ranged among fields from $0 \%$ to $88 \%$, whereas tipburn severity, defined as the mean number of affected leaves per plant, varied among fields from 0 to 2.8. There were no apparent relationships (no significant linear or quadratic trends) among soil $\mathrm{Ca}$ availability, inner leaf $\mathrm{Ca}$ concentration, or tipburn severity (Fig. 2A-C); in fact, the field with the most severe tipburn had both the highest saturated paste soil $\mathrm{Ca}$ and the highest leaf

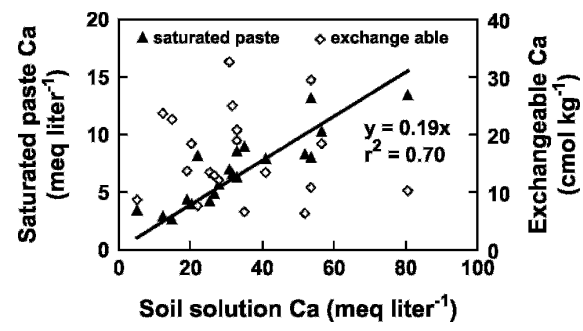

Fig. 1. Relationship between soil calcium (Ca) extracted by the ammonium acetate or saturated paste methods and $\mathrm{Ca}$ in soil solution obtained by centrifugation. Regression between ammonium acetate and soil solution nonsignificant at $P<0.05$; regression between saturated paste and soil solution significant at $P<0.01$.

Table 1. Summary of soil characteristics and crop management practices for the 2005 and 2006 calcium (Ca) fertigation trials.

\begin{tabular}{lccc}
\hline & Trial 1 & Trial 2 & Trial 3 \\
\hline Soil characteristics & Sandy clay loam & Sandy loam & Sandy loam \\
Texture & 7.0 & 6.8 & 6.9 \\
$\mathrm{pH}$ & 4.4 & 8.9 & 8.6 \\
Saturated paste Ca (mmolc $\left.\cdot \mathrm{L}^{-1}\right)$ & 54 & 52 & 59 \\
$(\%$ of cations, charge basis) & Harvest Gold & Harvest Gold & Sunbelt \\
Cultivar & 360 & 370 & 170 \\
Seasonal N total $\left(\mathrm{kg} \cdot \mathrm{ha}^{-1}\right)$ & 22 July, 2 Aug. & 22 Aug., 6 Sept. & 14 Aug. \\
Ca fertigation date $(\mathrm{s})$ & 9 Aug., 2005 & 15 Sept., 2005 & 21 Aug., 2006 \\
Harvest date & &
\end{tabular}

$\mathrm{Ca}$ concentration, suggesting that factors other than soil $\mathrm{Ca}$ availability governed tipburn development. Limited transpiration may have been such a factor. Two of the three fields with significant tipburn had the lowest transpiration indices over the final 2 weeks of growth (Fig. 2D). These two fields, both harvested 27 July 2005, were located in the coastal region near Castroville. Persistent marine fog from 9 to $6 \mathrm{~d}$ before harvest resulted in the low transpiration index over that period (Fig. 3).

Calcium fertigation effects on lettuce. Applying $\mathrm{Ca}$ fertilizers through drip irrigation had no significant effect on romaine yield or inner leaf $\mathrm{Ca}$ concentration in any trial (Table 2). Inner leaf Ca was consistent across trials despite substantial differences in soil $\mathrm{Ca}$ availability. No tipburn was observed in two of the trials; in one trial, a low level of tipburn was present, but $\mathrm{Ca}$ fertigation did not reduce its incidence.

\section{Discussion}

Soil $\mathrm{Ca}$ availability appeared to play no substantive role in the development of tipburn in romaine lettuce grown under field conditions representative of the Salinas Valley. This confirmed prior observations that tipburn severity was generally unrelated to soil $\mathrm{Ca}$ status and could not be reduced through soil $\mathrm{Ca}$ application (Bangerth, 1979; Collier and Tibbitts, 1982; Misaghi and Matyac, 1981). The lack of correlation between soil $\mathrm{Ca}$ availability and tipburn incidence, and the lack of crop response to $\mathrm{Ca}$ fertigation, can be attributed to two main factors: generally high soil $\mathrm{Ca}$ availability in the soils of this region and the confounding effects of environmental factors on plant $\mathrm{Ca}$ uptake.

Ca dominates the base exchange in central California soils. Saturated paste extracts from the soils used in the laboratory extraction methods comparison averaged 6.9 mmolc $\cdot \mathrm{L}^{-1} \mathrm{Ca}$, whereas those from the tipburn field survey averaged $7.7 \mathrm{mmolc} \cdot \mathrm{L}^{-1}$. Given the fivefold difference between saturated paste $\mathrm{Ca}$ and soil solution $\mathrm{Ca}$, soil $\mathrm{Ca}$ availability was very high across the soils tested. Soil solution $\mathrm{Ca}$ in the extraction methods comparison averaged $34 \mathrm{mmolc} \cdot \mathrm{L}^{-1}$, representing $57 \%$ of cation charges. By comparison, hydroponic nutrient solutions used in greenhouse vegetable production, formulated to provide optimum nutrient balance, typically range between 5 and 10 mmolc $\cdot \mathrm{L}^{-1} \mathrm{Ca}$, representing $30 \%$ to $50 \%$ of cations in the solution (Hanna, 1998; Jones, 1997).

At the modest application rates used, which reflected current industry practices, $\mathrm{Ca}$ fertigation had no measurable effect on crop Ca status, undoubtedly in part because the application represented an insignificant increase in soil $\mathrm{Ca}$ availability. Fertigation trial 1 had the lowest soil Ca availability (19 mmolc $\cdot \mathrm{L}^{-1}$ in soil solution). At field capacity moisture content ( $21 \%$ by weight $)$ and typical field bulk density $\left(1.3 \mathrm{~g} \mathrm{~cm}^{-3}\right)$, this soil had 

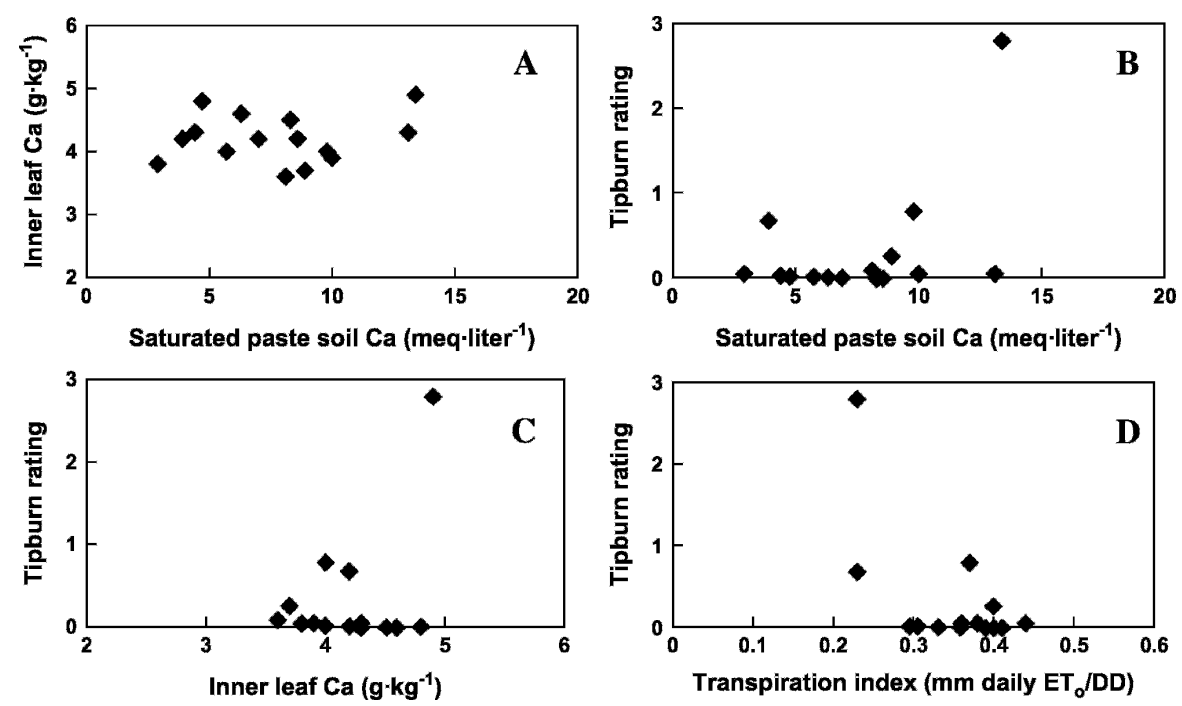

Fig. 2. Relationships among saturated paste soil calcium $(\mathrm{Ca})$, inner leave $\mathrm{Ca}$, transpiration index, and tipburn rating in the tipburn survey fields. Tipburn rating is mean number of affected leaves per plant; transpiration index is the mean daily value over the final 2 weeks before harvest.

greater than $300 \mathrm{~kg} \cdot \mathrm{ha}^{-1} \mathrm{Ca}$ in the top $30 \mathrm{~cm}$. By comparison, each fertigation of $17 \mathrm{~kg} \cdot \mathrm{ha}^{-1}$ Ca represented less than $6 \%$ of the $\mathrm{Ca}$ in soil solution. The failure of $\mathrm{Ca}$ fertigation to increase lettuce $\mathrm{Ca}$ concentration supported the observations of Misaghi and Matyac (1981); working in California and Arizona,

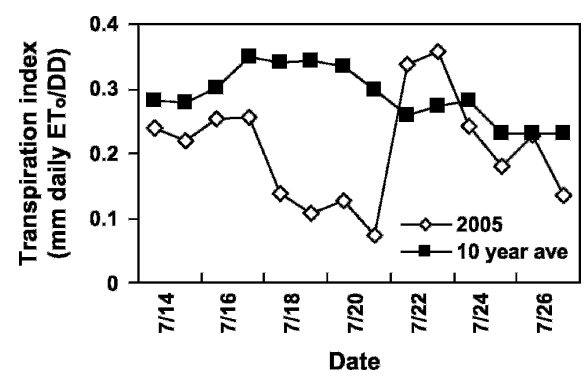

Fig. 3. Transpiration index ( $\mathrm{mm} \mathrm{ET}_{\mathrm{o}} /$ degree day) for Castroville, CA, site of two 2005 survey fields with significant tipburn; data represent the final $14 \mathrm{~d}$ before harvest.

Table 2. Effects of calcium fertigation on romaine lettuce yield, inner leaf calcium (Ca) concentration, and tipburn severity.

\begin{tabular}{|c|c|c|c|c|c|}
\hline Trial & Ca Treatment ${ }^{z}$ & $\begin{array}{l}\text { Mean plant } \\
\text { mass (kg) }\end{array}$ & $\begin{array}{c}\text { Marketable plants } \\
(\%)\end{array}$ & Tipburn rating ${ }^{\mathrm{y}}$ & Leaf Ca $\left(\mathrm{g} \cdot \mathrm{kg}^{-1}\right)$ \\
\hline \multirow[t]{5}{*}{$\overline{1}$} & No $\mathrm{Ca}$ & 0.76 & 97 & 0 & 4.3 \\
\hline & $\mathrm{CN}$ & 0.79 & 98 & 0 & 4.7 \\
\hline & CTS & 0.79 & 97 & 0 & 4.6 \\
\hline & $\mathrm{CC}$ & 0.80 & 98 & 0 & 4.4 \\
\hline & & NS & NS & NS & NS \\
\hline \multirow[t]{5}{*}{2} & No $\mathrm{Ca}$ & 0.84 & 98 & 0.3 & 3.7 \\
\hline & $\mathrm{CN}$ & 0.85 & 98 & 0.4 & 4.1 \\
\hline & CTS & 0.83 & 97 & 0.2 & 3.9 \\
\hline & $\mathrm{CC}$ & 0.83 & 98 & 0.2 & 3.9 \\
\hline & & NS & NS & NS & NS \\
\hline \multirow[t]{4}{*}{3} & No $\mathrm{Ca}$ & 0.72 & 97 & 0 & 4.2 \\
\hline & $\mathrm{CN}$ & 0.70 & 98 & 0 & 3.9 \\
\hline & CTS & 0.69 & 95 & 0 & 4.3 \\
\hline & & NS & NS & NS & NS \\
\hline
\end{tabular}

${ }^{\mathrm{z}} \mathrm{CN}=$ calcium nitrate; $\mathrm{CTS}=$ calcium thiosulfate $\mathrm{CC}=$ calcium chloride .

${ }^{\mathrm{y}}$ Mean number of leaves per plant showing tipburn.

$\mathrm{NS}=\mathrm{Ca}$ treatments not significantly different at $P<0.05$. control measures are limited. Salinas Valley growers currently attempt to minimize tipburn incidence by growing less tipburn-susceptible cultivars during the summer and by concentrating summer production away from the coastal area, practices supported by our results and those of Ryder and Waycott (1998). However, the application of $\mathrm{Ca}$ fertilizers is clearly an ineffective practice.

These findings have relevance for other production areas and for $\mathrm{Ca}$ disorders affecting other horticultural crops. The $\mathrm{Ca}$ characteristics of the soils evaluated in this study are not unique to California. Throughout the western United States, alkaline, mineral soils containing free lime are common. In such soils, at normal application rates, the application of $\mathrm{Ca}$ fertilizer is unlikely to substantively increase crop $\mathrm{Ca}$ uptake or reduce the incidence or severity of Ca-related disorders. In addition to liming acid soil for $\mathrm{pH}$ adjustment, there are several valid uses for soil applied $\mathrm{Ca}$ : improving infiltration of rain or irrigation water of low electrical conductivity and reclaiming sodic soil (Shainberg et al., 1989). However, for these uses, the relatively high application rates required for efficacy favor the use of an inexpensive $\mathrm{Ca}$ source such as lime or gypsum rather than the more expensive $\mathrm{Ca}$ fertilizer products evaluated here.

In summary, soils used for lettuce production in central California have high $\mathrm{Ca}$ availability. Tipburn severity is unrelated to soil $\mathrm{Ca}$ availability and therefore is unlikely to be reduced by soil $\mathrm{Ca}$ fertilization.

\section{Literature Cited}

Ashkar, S.A. and S.K. Ries. 1971. Lettuce tipburn as related to nutrient imbalance and nitrogen composition. J. Amer. Soc. Hort. Sci. 96:448454.

Bangerth, F. 1979. Calcium-related disorders of plants. Ann. Rev. Phytopath. 17:97-122.

Clarkson, D.T. 1984. Calcium transport between tissues and its distribution in the plant. Plant Cell Environ. 7:449-456.

Collier, G.F. and T.W. Tibbitts. 1982. Tipburn of lettuce. Hort. Rev. (Amer. Soc. Hort. Sci.) 4:49-65.

Cox, E.F., J.M.T. McKee, and A.S. Dearman. 1976. The effect of growth rate on tipburn occurrence in lettuce. J. Hort. Sci. 51:297-309.

Cresswell, G.C. 1991. Effect of lowering nutrient solution concentration at night on leaf calcium levels and the incidence of tipburn in lettuce (var. Gloria). J. Plant Nutr. 14:913-924.

Frantz, J.M., G. Rithie, N.N. Cometti, J. Robinson, and B. Bugbee. 2004. Exploring the limits of crop productivity: Beyond the limits of tipburn in lettuce. J. Amer. Soc. Hort. Sci. 129:331338 .

Goldhamer, D.A. and R.L. Snyder. 1989. Irrigation scheduling: A guide for efficient on-farm water management. Univ. Calif. Coop. Ext. Bul. 21454.

Goto, E. and T. Takakura. 1992. Prevention of lettuce tipburn by supplying air to inner leaves. Trans. ASAE 35:641-645.

Hanna, J.J. 1998. Greenhouses: Advanced technology for protected horticulture. CRC Press, New York. 
Jones, J.B. 1997. Hydroponics: A practical guide for the soilless grower. St. Lucie Press, Boca Raton, FL.

Meyer, G.A. and P.N. Keliher. 1992. An overview of analysis by inductively coupled plasmaatomic emission spectrometry, p. 473-505. In A. Montaser and D.W. Golightly (eds.). Inductively coupled plasmas in analytical atomic spectrometry. VCH Publishers Inc., New York.

Misaghi, I.J. and C.A. Matyac. 1981. Soil and foliar applications of calcium chloride and calcium nitrate to control tipburn of head lettuce. Plant Dis. 65:821-822.

Rao, R.R. 1966. Studies on the environmental factors controlling tipburn of lettuce. Univ. Wisconsin, Madison, PhD Diss.

Rhoades, J.D. 1982. Soluble salts, p. 167-179. In A.L. Page (ed.). Methods of soil analysis, Part 2: Chemical and microbiological properties.
Monograph Number 9, Amer. Soc. Agron., Madison, WI.

Ryder, E.J. and W. Waycott. 1998. Crisphead lettuce resistant to tipburn: Cultivar tiber and eight breeding lines. HortScience 33:903-904.

Sah, R.N. and R.O. Miller. 1992. Spontaneous reaction for acid dissolution of biological tissues in closed vessels. Anal. Chem. 64:230-233.

Shainberg, I., M.E. Summer, W.P. Miller, W.P.W. Farina, M.A. Pavin, and M.V. Fey. 1989. Use of gypsum on soils: A review. Adv. Soil Sci. 9:1-112.

Sonneveld, C. and J. van den Ende. 1975. The effect of some salts on head weight and tipburn of lettuce and on fruit production and blossomend rot of tomatoes. Neth. J. Agr. Sci. 23:191201.

Thibault, D.H. and M.I. Sheppard. 1992. A disposable system for soil pore-water extraction by centrifugation. Commun. Soil Sci. Plant Anal. 23:1629-1641.

Thibodeau, P.O. and P.L. Minotti. 1969. The influence of calcium on the development of lettuce tipburn. J. Amer. Soc. Hort. Sci. 94:372-376.

Thomas, G.W. 1982. Exchangeable cations, p. 159-165. In A.L. Page (ed.). Methods of soil analysis, Part 2: Chemical and microbiological properties. Monograph Number 9, Amer. Soc. Agron., Madison, WI.

Tibbitts, T.W. and R.R. Rao. 1968. Light intensity and duration in the development of lettuce tipburn. Proc. Amer. Soc. Hort. Sci. 93:454461.

Wien, H.C. and D.S. de Villiers. 2005. Inducing lettuce tipburn with relative humidity modification. HortScience 40:1053 (abstr.). 